\title{
An unusual case of abdominal pains
}

\author{
Muhammad Hassan Tahir, ${ }^{1}$ Mohammad Y Ibrahim, ${ }^{1}$ Naresh Kumar, ${ }^{1}$ Vinuta Mohan ${ }^{2}$
}

'Internal Medicine, St Francis Medical Center, Trenton, New Jersey, USA

${ }^{2}$ Endocrinology, St Francis Medical Center, Trenton, New Jersey, USA

Correspondence to Dr Muhammad Hassan Tahir, dochtahir@gmail.com

Accepted 8 May 2017

\section{DESCRIPTION}

A 55-year-old African American man presented to the emergency room with 3 days of new-onset right-sided flank and abdominal pains. His abdominal pains were dull in nature, constant, moderate in severity (approximately 6 out of 10) and radiated to his back and right flank regions. There were no aggravating factors but the patient reported temporary relief with over-the-counter acetaminophen. The pains were associated with mild nausea and vomiting but he denied diarrhoea, constipation, weight loss, fevers or other associated symptoms. His only known medical history was hypertension, controlled with lisinopril. Surgical, social and family history were unremarkable. Other than abdominal pains, a complete review of systems was negative. His blood pressure was $117 / 78 \mathrm{~mm} \mathrm{Hg}$ and his pulse was $82 \mathrm{bpm}$. His physical examination revealed right flank and right lower quadrant abdominal pain without rebound or guarding.

He underwent an abdominal CT scan which showed a $5.2 \mathrm{~cm} \times 4.2 \mathrm{~cm}$ hypodensed solid right

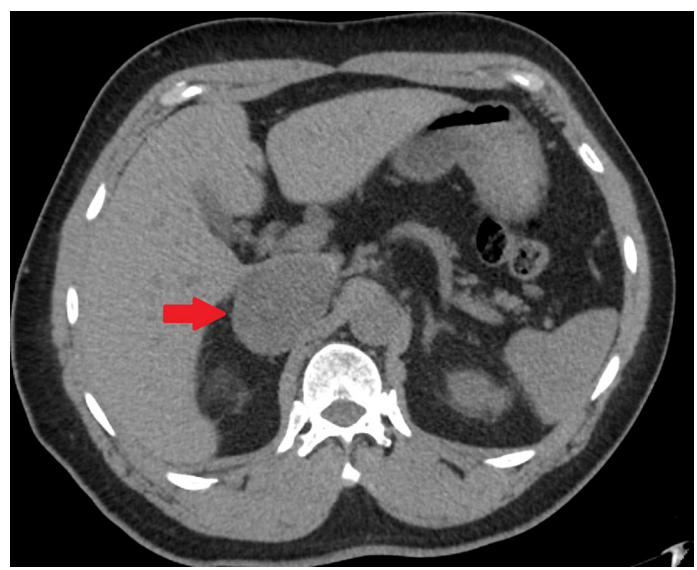

Figure 1 Non-contrast CT abdomen axial view shows a hypodense solid $5.2 \mathrm{~cm} \times 4.2 \mathrm{~cm}$ right adrenal mass measuring 22 Hounsfield units, compressing the inferior vena cava.
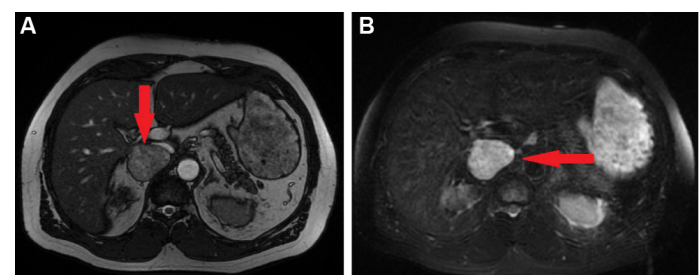

Figure 2 (A) MRI abdomen axial T2 view shows a heterogeneous right adrenal mass measuring $5.2 \mathrm{~cm} \times 4.8 \mathrm{~cm} \times 3.6 \mathrm{~cm}$ displacing the inferior vena cava and the liver. (B) MRI abdomen axial diffusion-weighted image shows a T2 hyperintensed right adrenal mass.

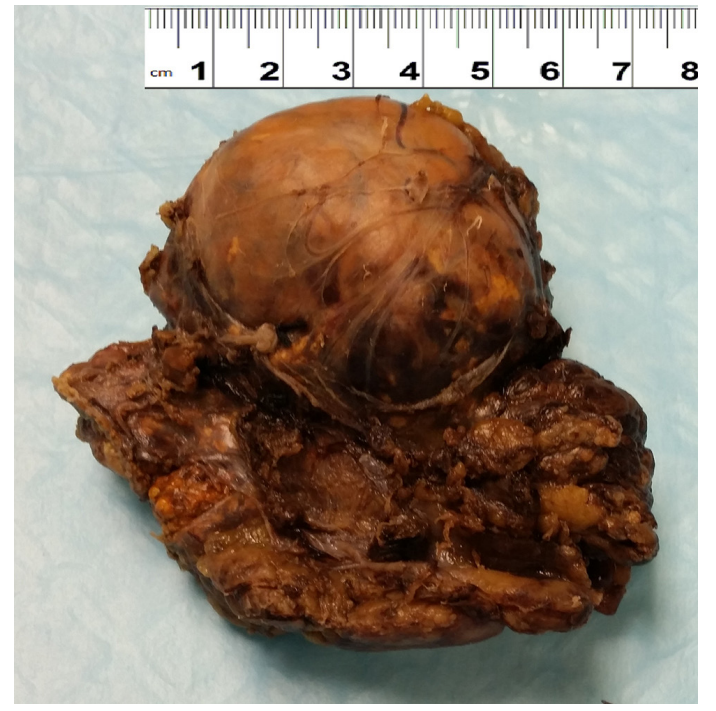

Figure 3 A $6 \mathrm{~cm}$ yellow-brown solid adrenal pheochromocytoma tumour, confined within the capsule.

adrenal mass measuring 22 Hounsfield units (figure 1). Subsequent abdominal MRI demonstrated a $5.2 \mathrm{~cm} \times 4.8 \mathrm{~cm} \times 3.6 \mathrm{~cm}$ heterogeneous right adrenal mass with mass effect on liver and inferior vena cava (figure 2A). Axial diffusion-weighted image of the MRI showed a heterogeneous, significantly T2 hyperintensed right adrenal mass (figure 2B). The patient's blood work showed markedly elevated plasma fractionated metanephrines $805 \mathrm{pg} / \mathrm{mL}(<57 \mathrm{pg} / \mathrm{mL})$ and elevated plasma normetanephrines $1938 \mathrm{pg} / \mathrm{mL}$ $(<148 \mathrm{pg} / \mathrm{mL})$ consistent with pheochromocytoma. He was started on phenoxybenzamine and metoprolol and underwent successful right adrenalectomy (figure 3). Histopathology was notable for chromaffin cells (figure 4A) with chromogranin A stain
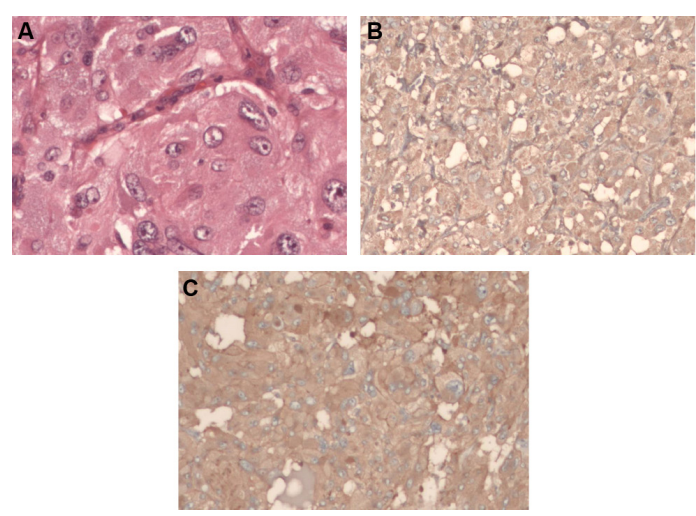

Figure 4 (A) H\&E stain showing nested tumour cells $(200 \times)$, (B) chromogranin A stain positive $(100 x),(C)$ synaptophysin stain positive $(100 x)$. 
positive (figure 4B) and synaptophysin stain positive (figure 4C), consistent with pheochromocytoma.

Pheochromocytoma is a catecholamine-producing tumour which usually arises from the adrenal medulla. If left untreated, it is potentially fatal because patients may develop hypertensive crisis, cardiac arrhythmias or myocardial infarction. It is extremely rare, with an annual incidence of two cases per million per year. ${ }^{1}$ Patients usually present with symptoms of excessive catecholamine production, such as palpitations, diaphoresis, headache and paroxysmal hypertension. Patients may also be asymptomatic or present with a variety of other symptoms mimicking other diseases, which may make diagnosis difficult. ${ }^{2}$

\section{Learning points}

- Pheochromocytoma is a rare disease in which patients typically present with palpitations, diaphoresis, headache and paroxysmal hypertension.

- Patients with pheochromocytoma may also present with atypical signs and symptoms which can delay diagnosis or make diagnosis difficult.

- It is crucial in patients with adrenal tumours, even when found incidentally, be evaluated for pheochromocytoma because it is a potentially fatal disease.
Given the large size of his tumour, our patient presumably presented with flank and abdominal pains secondary to localised mass effects. Patients with pheochromocytoma presenting as our patient did is quite unusual and seldom reported. ${ }^{3}$

Acknowledgements The authors would like to acknowledge Dr Brendan Fitzpatrick and the Department of Pathology at Our Lady of Lourdes hospital, Camden, Nj for their help in acquiring the images. The authors also thank Dr. Sara Wallach, Chief And Chairperson of the Department of Medicine at Saint Francis Medical Center, Trenton, NJ for her assistance with journal selection as well as her support for the Department of Endocrinology at our institution.

Contributors MHT is the primary author of the paper. MHT and VM reviewed all of the literature, wrote the article and edited the original manuscript to prepare for submission. MYI and NK reviewed previously published articles and helped with acquiring images.

Competing interests None declared.

\section{Patient consent Obtained.}

Provenance and peer review Not commissioned; externally peer reviewed.

(C) BMJ Publishing Group Ltd (unless otherwise stated in the text of the article) 2017. All rights reserved. No commercial use is permitted unless otherwise expressly granted.

\section{REFERENCES}

1 Beard CM, Sheps SG, Kurland LT, et al. Occurrence of pheochromocytoma in Rochester, Minnesota, 1950 through 1979. Mayo Clin Proc 1983;58:802.

2 Guerrero MA, Schreinemakers JM, Vriens MR, et al. Clinical spectrum of pheochromocytoma. J Am Coll Surg 2009;209:727-32.

3 Karumanchery R, Nair JR, Hakeem A, et al. An unusual case of back pain: a large pheochromocytoma in an 85 year old woman. Int J Surg Case Rep 2012;3:16-18.

Copyright 2017 BMJ Publishing Group. All rights reserved. For permission to reuse any of this content visit http://group.bmj.com/group/rights-licensing/permissions.

BMJ Case Report Fellows may re-use this article for personal use and teaching without any further permission.

Become a Fellow of BMJ Case Reports today and you can:

- Submit as many cases as you like

- Enjoy fast sympathetic peer review and rapid publication of accepted articles

- Access all the published articles

- Re-use any of the published material for personal use and teaching without further permission

For information on Institutional Fellowships contact consortiasales@bmjgroup.com

Visit casereports.bmj.com for more articles like this and to become a Fellow 